\title{
Phosphorus accumulation in a southern Brazilian Ultisol amended with pig manure for
} nine years

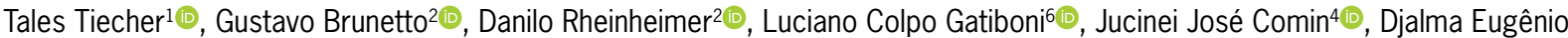 \\ Schmitt ${ }^{3}$, Tadeu Luis Tiecher ${ }^{5}$, Vitor Gabriel Ambrosini ${ }^{1 *}$ (i)
}

IUniversidade Federal do Rio Grande do Sul/Faculdade de Agronomia - Depto. de Solos, Av. Bento Gonçalves, 7712 91540-000 - Porto Alegre, RS - Brasil.

2Universidade Federal de Santa Maria/Centro de Ciências Rurais - Depto. de Solos, Av. Roraima, 1000 - $97105-900$ Santa Maria, RS - Brasil.

${ }^{3}$ Universidade Federal de Santa Catarina/Centro de Ciências Rurais - Depto. de Agricultura, Biodiversidade e Florestas Rod. Ulysses Gaboardi, 3000 - 89520-000 - Curitibanos, $\mathrm{SC}$ - Brasil.

${ }^{4}$ Universidade Federal de Santa Catarina/Centro de Ciências Agrárias - Depto. de Engenharia Rural, Rod. Admar Gonzaga, 1346 - 88034-000 - Florianópolis, SC - Brasil. 5Instituto Federal do Rio Grande do Sul, Campus Restinga, R. Alberto Hoffmann, 285 - 91791-508 - Porto Alegre, RS - Brasil. ${ }^{6}$ North Carolina State University - Department of Crop and Soil Sciences, 101 Derieux St, Raleigh NC 27695, USA.

*Corresponding author <vgambrosini@gmail.com>

Edited by: Francesco Montemurro

Received June 24, 2019

Accepted October 21, 2019
ABSTRACT: This study evaluated P pools after nine years of successive application of either pig slurry (PS) or deep pig litter (DL) in a no-till Ultisol from southern Brazil. The experiment was established in Dec 2002 with the treatments control, application of 90 and $180 \mathrm{~kg} \mathrm{~N} \mathrm{ha}^{-1} \mathrm{~N}$ as PS and as DL. In Mar 2010, soil samples were taken at six layers up to $30 \mathrm{~cm}$ deep. Total organic and inorganic $\mathrm{P}$ were assessed by the ignition method, and $\mathrm{P}$ compounds classes were evaluated by ${ }^{31} \mathrm{P}-\mathrm{NMR}$ spectroscopy. Total soil $\mathrm{P}$ increased proportionally with the $\mathrm{P}$ amount applied via DL and PS. Only DL application increased soil organic $P$, mainly at the highest dose and in the uppermost soil layers. The application of high doses of manure to these soils under notill to meet crop $\mathrm{N}$ demands significantly increased $\mathrm{P}$ accumulation at the soil surface, especially with DL. This, in turn, increases the risk of contamination of water bodies due to $P$ transfer from soil to rivers via runoff. The ignition method overestimates organic P compared to P-NMR. The highest proportion of organic $\mathrm{P}$ estimated by the ignition and P-NMR methods, at surface layers in the control suggests that inorganic $P$ is added to the plots treated, increasing inorganic $P$ and decreasing organic $\mathrm{P}$. Moreover, with no $\mathrm{P}$ additions to the control, inorganic soil $\mathrm{P}$ is removed by plants, causing an apparent increase in the organic $\mathrm{P}$ proportion.

Keywords: P-NMR, organic P, manure, orthophosphate

\section{Introduction}

Brazil is the world's fourth largest pork producer (3.75 million tons; ABPA, 2018). Sixty-three percent of pork production is concentrated in southern Brazil, mainly in feedlot systems that generate a large amount of pig slurry (PS), composed of urine, feces, and water used for cleaning the facilities. To reduce PS volume, other waste materials, such as wood shavings (sawdust), are added, resulting in a material called deep pig litter (DL). Both PS and DL are alternatives to mineral $\mathrm{P}$ fertilizer in agriculture, an important consideration due to the global rock phosphate scarcity predicted for the next decades (Withers et al., 2018). Estimates of $\mathrm{P}$ excreted as pig manure in Brazil are about 123,000 $\mathrm{Mg} \mathrm{yr}^{-1}$ (Tiecher et al., 2014), which accounts for $3.2 \%$ of national annual phosphate fertilizers consumption (IFA, 2013). In southern Brazil, PS and DL application rates are usually based on plant $\mathrm{N}$ demand; however, the $\mathrm{N}: \mathrm{P}$ ratio in manure is unbalanced according to crop demand. Thus, applying PS and DL to meet crop $\mathrm{N}$ requirements adds an excess of $\mathrm{P}$, which accumulates in the soil, increasing the risk of environmental pollution over time (Gatiboni et al., 2015).

Phosphorus added via animal manure is distributed in soil inorganic and organic pools (Gatiboni et al., 2013). Organic $P$ is a nutrient reservoir that may become available to plants and soil microbial biomass (Steffens et al., 2010). When P is added to meet plant demand, soil organic $P$ is preserved (Gatiboni et al., 2007) if sufficient inorganic $\mathrm{P}$ as phosphate is available to meet microorganism and crop requirements. However, when phosphate additions are lower than crop needs, organic $P$ might be consumed (Chen et al., 2004).

Several studies using ${ }^{31} \mathrm{P}-\mathrm{NMR}$ have reported on high contents of inorganic and bioavailable $\mathrm{P}$ in PS, mainly as orthophosphate (from 77 to $99 \%$ of total P; Turner and Leytem, 2004; Tiecher et al., 2014), due to enzyme production in swine hindguts that mineralize organic P into orthophosphate. Moreover, swine feeds contain phytases as a supplement that help to mineralize organic $\mathrm{P}$ in grains used in feeds, making organic $\mathrm{P}$ easily mineralizable or hydrolysable in the soil (He et al., 2008; Abdala et al., 2015). The effect of PS application on P-forms assessed by ${ }^{31} \mathrm{P}-\mathrm{NMR}$ has been evaluated under temperate (Koopmans et al., 2003) and subtropical (Gatiboni et al., 2013) conditions. However, distribution of $\mathrm{P}$ compound classes in the soil under DL application has not been studied, although it is known that mixing animal manure with sawdust provides more complex and recalcitrant forms of carbon $(\mathrm{C})$ in the soil (Mante and 
Agblevor et al., 2010). Therefore, an increase of more recalcitrant organic $\mathrm{P}$ in the soil is expected when manure is applied as DL rather than as PS, especially at higher rates in the long-term. This study evaluated P pools and compound classes after nine years of successive PS and DL application in a no-till Ultisol in southern Brazil.

\section{Material and Methods}

\section{Site description and treatments}

The experiment was established on a pig farm in Braço do Norte, Santa Catarina State (SC), southern Brazil $\left(28^{\circ} 14^{\prime} \mathrm{S}, 49^{\circ} 13^{\prime} \mathrm{W}\right.$, altitude of $300 \mathrm{~m}$, with undulated relief. The soil was classified as a Typic Hapludult (Soil Survey Staff, 2014), with medium texture (sandy clay loam) in the A horizon. Annual mean temperature and rainfall were $18.7^{\circ} \mathrm{C}$ and $1,471 \mathrm{~mm}$, respectively. Before establishing the experiment trial in Dec 2002, the area was covered by natural grassland consisting mainly of Paspalum notatum Flügge (Poaceae), P. plicatulum Michx. (Poaceae), Eryngium ciliatum Cham. \& Schltdl (Apiaceae), and Stylosanthes montevidensis Vogel (Fabaceae), with a sporadic history of PS applications on the soil surface. At the beginning of the experiment, characteristics of the $0-10 \mathrm{~cm}$ soil layer were: $330 \mathrm{~g} \mathrm{~kg}^{-1}$ of clay and 33 $\mathrm{g} \mathrm{kg}^{-1}$ of organic matter, determined according to the methodology described by Embrapa (1997); pH 5.1, determined in distilled water with a glass electrode $(\mathrm{pH}$ in water at a ratio of $1: 1 \mathrm{v} / \mathrm{v}$ ); $3.0,0.8$, and $0.8 \mathrm{cmol}_{\mathrm{c}} \mathrm{kg}^{-1}$ of exchangeable calcium $(\mathrm{Ca})$, magnesium $(\mathrm{Mg})$, and aluminum (Al), respectively, extracted by $\mathrm{KCl} 1.0 \mathrm{~mol}$ $\mathrm{L}^{-1}$ (soil:extractant ratio of $\left.1: 20\right) ; 19$ and $130 \mathrm{mg} \mathrm{kg}^{-1}$ of available $\mathrm{P}$ and potassium $(\mathrm{K})$, respectively, extracted by Mehlich-1 (soil:extractant ratio 1:10, with $\mathrm{P}$ determined by the molybdenum-blue method (Murphy and Riley, 1962); cation exchange capacity of $11.9 \mathrm{cmol}_{\mathrm{c}} \mathrm{kg}^{-1}$; 42 $\%$ base saturation and $16 \% \mathrm{Al}$ saturation, calculated according CQFS-RS/SC (2016). Before implementing the experiment, 6.0 Mg ha ${ }^{-1}$ of limestone was applied (total neutralizing power $=87.5 \%$ ) on the soil surface, without incorporation, to raise the soil $\mathrm{pH}$ to 6.0. In Jan 2003, the pasture was desiccated using herbicides and subsequently the crops were all sown under a no-tillage system.

The experiment was carried out in a randomized block with three replications of five treatments, applied for the first time in Jan 2003. Each plot measured $4.5 \times$ $6.0 \mathrm{~m}\left(27 \mathrm{~m}^{2}\right)$. Five treatments were applied annually from 2003 to 2010: control; application of 90 and $180 \mathrm{~kg}$ nitrogen (N) ha ${ }^{-1}$ as PS (PS90 and PS180), and 90 and 180 $\mathrm{kg} \mathrm{N} \mathrm{ha}^{-1}$ as DL (DL90 and DL180). The $\mathrm{N}$ rates were chosen based on $\mathrm{N}$ recommendation $\left(90 \mathrm{~kg} \mathrm{~N} \mathrm{ha}^{-1} \mathrm{yr}^{-1}\right)$ for maize (Zea mays L.) grown in rotation with black oat (Avena strigosa Schreb) in Rio Grande do Sul and Santa Catarina States (CQFS-RS/SC, 2016). The rate of $180 \mathrm{~kg}$ $\mathrm{N} \mathrm{ha}^{-1} \mathrm{yr}^{-1}$ (twice the recommended rate) was also used to represent the region reality, where animal manure is applied by farmers in croplands without technical criteria and often exceeds the maximum annual rate allowable.
The PS was collected from the farm where the experiment was carried out. The DL was obtained from the Federal Agrotechnical School in Concórdia, Santa Catarina, Brazil, where pigs in the terminal phase $(100-150 \mathrm{~kg})$ were reared on wood shavings. The PS and DL typically used have C:N ratios of 2.6 and 9.8, respectively (Table 1). More information on the main chemical characteristics of the PS and DL used in the experimental period (20022010) is presented in Table 1.

Maize and black oat were grown in crop succession every year. Maize was sown in rows annually in Nov, with a density of 50,000 plants per hectare. Black oat was sown in rows every year in May using $90 \mathrm{~kg} \mathrm{ha}^{-1}$ of seed. Only maize was harvested and crop residues were left on the ground. The only sources of nutrients added to the experiment from 2003 to 2010 were PS and DL. From 2003 to 2010, PS (PS90 and PS180) treatments were applied to soil surface at four equivalent periods: before planting maize, 51 and 95 days after planting maize, and 15 days after planting black oat, totaling 32 pig slurry applications from 2003 to 2010. The DL (DL90 and DL180) treatments were applied to the soil surface once a year at 15 to 30 days before planting maize. Eight DL applications were made from 2003 to 2010. The total amount of P applied from 2003 to 2010 was 0, 303, 606, 825 , and $1650 \mathrm{~kg} \mathrm{ha}^{-1}$ in the treatments control, PS 90, PS 180, DL 90, and DL 180, respectively.

\section{Soil sampling}

In Mar 2010, soil was sampled at 0-2.5, 2.5-5, 5-10, $10-15,15-20$, and $20-30 \mathrm{~cm}$ layers from a trench opened in the center of each plot, and were subsequently air-dried and sieved through a 2-mm mesh. The remaining plant residues were removed manually. Then, the soil was mixed using a mortar and pestle, sieved through a $1 \mathrm{~mm}$ mesh and stored for analyses.

\section{Total organic and inorganic $\mathbf{P}$}

Total soil $\mathrm{P}$ (Total-P) was determined by digestion with $\mathrm{H}_{2} \mathrm{SO}_{4}$ and $\mathrm{H}_{2} \mathrm{O}_{2}$ in the presence of saturated $\mathrm{MgCl}_{2}$ (Olsen and Sommers, 1982) followed by the colorimetric analysis (Murphy and Riley, 1962). Total organic P (Org-P) was determined by the ignition method, based on the difference between the concentrations of $\mathrm{P}$ extracted with $0.5 \mathrm{~mol} \mathrm{~L}^{-1} \mathrm{H}_{2} \mathrm{SO}_{4}$ from ignited $\left(550{ }^{\circ} \mathrm{C}, 2 \mathrm{~h}\right)$ and non-ignited samples followed by the colorimetric analysis (Olsen and Sommers, 1982). Then, total inorganic P (Inorg-P) was calculated by the difference between Total-P and Org-P.

Table 1 - Main chemical characteristics and quantity of nutrients of pig slurry (PS) and deep pig litter (DL) used in the experimental period (2002-2010).

\begin{tabular}{lcccccccc}
\hline Manure & Dry matter & $\mathrm{C} / \mathrm{N}$ ratio & $\mathrm{C}$ & $\mathrm{N}$ & $\mathrm{P}$ & $\mathrm{K}$ & $\mathrm{Cu}$ & $\mathrm{Zn}$ \\
\cline { 5 - 9 } & $\mathrm{g} \mathrm{kg}^{-1}$ & & & $\mathrm{~g} \mathrm{~kg}^{-1}$ & $\mathrm{DM}$ & & & $-\mathrm{mg} \mathrm{kg}^{-1}-$ \\
Pig slurry & 21 & 2.6 & 289 & 112 & 89.4 & 62.3 & 0.82 & 0.44 \\
Deep pig litter & 489 & 9.7 & 370 & 38 & 66.4 & 46.0 & 0.70 & 0.92 \\
\hline
\end{tabular}




\section{$P$ compound classes assessed by ${ }^{31} \mathrm{P}-\mathrm{NMR}$}

The ${ }^{31} \mathrm{P}-\mathrm{NMR}$ analysis was performed with ten $1.0 \mathrm{~g}$ subsamples of dried soil from the $0-2.5 \mathrm{~cm}$ soil layer in $15 \mathrm{~mL}$ centrifuge tubes containing $10 \mathrm{~mL}$ of 0.25 mol NaOH L ${ }^{-1}+50$ mmol EDTA L ${ }^{-1}$ (Cade-Menun and Preston, 1996). The tubes were shaken for $4 \mathrm{~h}$ in an endover-end shaker at $25{ }^{\circ} \mathrm{C}$. After centrifugation at 2510 $\times \mathrm{g}$ for $15 \mathrm{~min}$, the extract of one subsample was used to estimate total $\mathrm{P}, \mathrm{Ca}, \mathrm{Mg}, \mathrm{Fe}$, and $\mathrm{Al}$ concentrations. The extracts of the other nine manure subsamples were combined and transferred into $100 \mathrm{~mL}$ snap cap tubes. The extracts were frozen and freeze-dried to complete dryness. Subsequently, the freeze-dried extract was dissolved in $2.7 \mathrm{~mL}$ of $0.25 \mathrm{~mol} \mathrm{~L}^{-1} \mathrm{NaOH}+50 \mathrm{mmol} \mathrm{L}^{-1}$ EDTA and $0.3 \mathrm{~mL} \mathrm{D}_{2} \mathrm{O}$, and the mixture vortex-stirred for $5 \mathrm{~min}$. After resting for $120 \mathrm{~min}$, the supernatant was separated by centrifugation $(2510 \times \mathrm{g}$ for $15 \mathrm{~min})$, filtered in cellulose filter with pore size of $0.45 \mu \mathrm{m}$, and transferred to $5 \mathrm{~mm}$ NMR tubes. The $\mathrm{P}$ spectra were obtained in a Bruker Advance DPX 400 spectrometer at a frequency of $162 \mathrm{MHz}$ with proton decoupling. A pulse angle of $90^{\circ}$ was used at $20^{\circ} \mathrm{C}$, with an acquisition time of $0.2 \mathrm{~s}$ and $15 \mathrm{~s}$ relaxation time. The number of scans was 12,000 .

Peaks were identified based on their chemical shifts (ppm) regarding an external orthophosphoric acid standard $(85 \%)$, and the orthophosphate peak was standardized to $6 \mathrm{ppm}$ for each sample during processing after analysis (Cade-Menun et al., 2010; Young et al., 2013; Liu et al., 2014; Giles et al., 2015). The software MestRe-C v 2.3a was used for peak area integration. Peak areas were calculated by integration on spectra processed with $1 \mathrm{~Hz}$ line broadening. The detected inorganic $\mathrm{P}$ compounds include orthophosphate 16.0 ppm) and pyrophosphate (-3.7 to $-3.8 \mathrm{ppm}$ ) (Figure 1). Organic $\mathrm{P}$ compounds detected from 5.9 and 3.6 ppm (Cade-Menun et al., 2010), which includes orthophosphate monoesters plus peaks resulting from the degradation of orthophosphate diesters during the NMR analysis (Young et al., 2013) (Figure 1). As the samples were not spiked with $\mathrm{P}$ compounds in this study, the precise identification of organic $\mathrm{P}$ compounds was not possible. Therefore, the interpretation was kept as simple as possible, presenting results as broad compound classes only (Cade-Menun, 2017).

\section{Statistical analyses}

The data were submitted to analysis of variance (ANOVA). When treatment effects were significant at $p$ $<0.05$ by the F-test, the differences between treatments were compared by the Tukey test at $p<0.05$.

\section{Results and Discussion}

\section{Organic and inorganic $P$ accumulation in soil}

The amount of $\mathrm{P}$ added to the soil was about 2.7 times higher with DL than with PS using the rate calculated to provide the same amount of $\mathrm{N}$, which

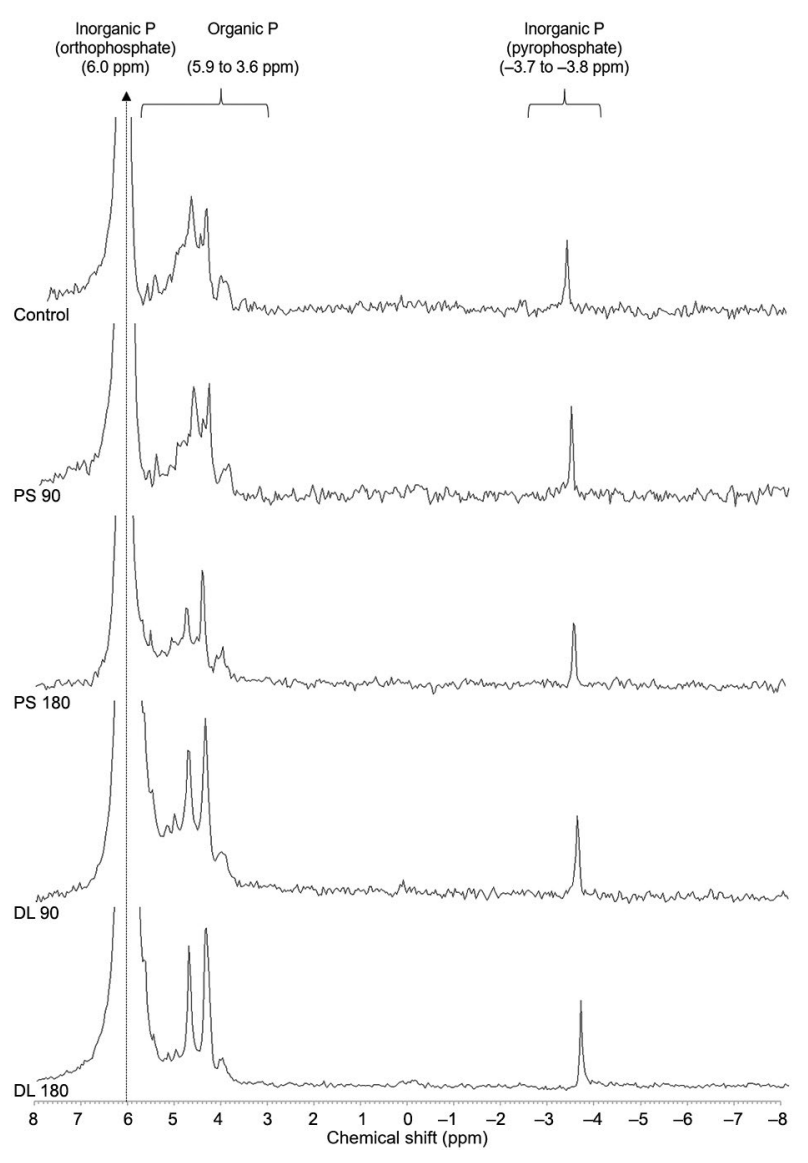

Figure 1 - Solution ${ }^{31} \mathrm{P}$ nuclear magnetic resonance spectra of $\mathrm{NaOH}$-EDTA extracts of soil $(0-2.5 \mathrm{~cm})$ from control treatment and for pig slurry (PS) or deep pig litter (DL) applied to supply 90 or $180 \mathrm{~kg} \mathrm{ha}^{-1}$ of $\mathrm{N}$. The spectrum is plotted with $1 \mathrm{~Hz}$ linebroadening.

resulted in a greater accumulation of soil inorganic and organic $\mathrm{P}$ in DL treatments (Table 2). These results demonstrate that the amount of applied $\mathrm{P}$ is one of the main aspects to determine the distribution and accumulation of $\mathrm{P}$ in the soil. As can be seen in Table 1 , DL treatments have lower $\mathrm{N}$ concentrations because in this pig breeding system, there is a significant loss of $\mathrm{N}$ by ammonia volatilization, resulting in increased concentrations of other nutrients, such as $\mathrm{P}$, compared to $\mathrm{N}$ content. As the manure dose applied in this study was defined as a function of plant $\mathrm{N}$ demand, the amounts of $\mathrm{P}$ applied in the DL treatments were higher than the PS treatments.

Another important factor controlling the dynamics of $\mathrm{P}$ accumulation in the soil is the way of applying swine manure: liquid (PS) or solid (DL). Although both PL and DL application increased total-P and inorganic $\mathrm{P}$ contents up to 15 and $20 \mathrm{~cm}$, respectively (Table 2), only the DL application increased organic P in the soil, mainly at the highest dose and up to 10 $\mathrm{cm}$ depth. Similar results have been observed under 
Table 2 - Total, organic and inorganic $P$ concentration in the soil for five treatments at six soil profile layers for pig slurry (PS) or deep pig litter (DL) applied to supply 90 or $180 \mathrm{~kg} \mathrm{ha}^{-1}$ of $\mathrm{N}$.

\begin{tabular}{|c|c|c|c|c|c|c|}
\hline$P$ form & $\begin{array}{l}\text { Soil layer } \\
(\mathrm{cm})\end{array}$ & Control & PS 90 & PS 180 & DL 90 & DL 180 \\
\hline $\mathrm{P}$ added $\left(\mathrm{kg} \mathrm{ha}^{-1}\right)$ & & 0 & 303 & 606 & 825 & 1650 \\
\hline \multirow{6}{*}{ Total P (mg kg-1) } & $0-2.5$ & $511 d$ & $738 \mathrm{~cd}$ & $1216 \mathrm{bc}$ & $1829 \mathrm{~b}$ & $3497 a$ \\
\hline & $2.5-5$ & $437 c$ & $645 c$ & $952 \mathrm{bc}$ & $1371 b$ & 3099 a \\
\hline & $5-10$ & $349 b$ & $399 \mathrm{~b}$ & 704 b & $903 a b$ & $1477 a$ \\
\hline & $10-15$ & $251 b$ & $261 \mathrm{ab}$ & $546 a b$ & $542 \mathrm{ab}$ & $939 a$ \\
\hline & $15-20$ & 190 & 200 & 336 & 303 & 558 \\
\hline & $20-30$ & 154 & 129 & 174 & 173 & 254 \\
\hline \multirow{6}{*}{ Organic $\mathrm{P}\left(\mathrm{mg} \mathrm{kg}^{-1}\right)$} & $0-2.5$ & $152 \mathrm{c}$ & $162 c$ & $227 c$ & $414 b$ & $717 \mathrm{a}$ \\
\hline & $2.5-5$ & $172 b$ & $146 b$ & $172 b$ & $269 b$ & $418 \mathrm{a}$ \\
\hline & $5-10$ & $156 \mathrm{~b}$ & $130 \mathrm{~b}$ & $75 b$ & $128 b$ & $312 a$ \\
\hline & $10-15$ & 119 & 115 & 79 & 109 & 95 \\
\hline & $15-20$ & 96 & 103 & 74 & 124 & 49 \\
\hline & $20-30$ & 68 & 77 & 71 & 66 & 50 \\
\hline \multirow{6}{*}{$\begin{array}{l}\text { Inorganic } \mathrm{P} \\
\left(\mathrm{mg} \mathrm{kg}^{-1}\right)\end{array}$} & $0-2.5$ & $359 d$ & $576 \mathrm{~cd}$ & 989 bc & $1415 \mathrm{~b}$ & $2780 a$ \\
\hline & $2.5-5$ & $265 c$ & $499 \mathrm{bc}$ & $781 \mathrm{bc}$ & $1102 \mathrm{~b}$ & $2681 \mathrm{a}$ \\
\hline & $5-10$ & $193 b$ & $268 b$ & $628 a b$ & $775 a b$ & $1165 a$ \\
\hline & $10-15$ & $131 b$ & $147 b$ & $466 \mathrm{ab}$ & $433 a b$ & $844 a$ \\
\hline & $15-20$ & $95 b$ & $97 b$ & $262 \mathrm{~b}$ & $179 \mathrm{~b}$ & $509 a$ \\
\hline & $20-30$ & 85 & 52 & 104 & 107 & 204 \\
\hline Organic:inorganic & $0-2.5$ & $0.42 \mathrm{a}$ & $0.28 \mathrm{~b}$ & $0.23 b$ & $0.29 b$ & $0.26 b$ \\
\hline \multirow{5}{*}{ P ratio } & $2.5-5$ & $0.65 a$ & $0.29 a b$ & $0.22 c$ & $0.24 \mathrm{c}$ & $0.16 c$ \\
\hline & $5-10$ & $0.81 \mathrm{a}$ & $0.49 a b$ & $0.12 \mathrm{c}$ & $0.17 c$ & $0.27 c$ \\
\hline & $10-15$ & $0.91 \mathrm{a}$ & $0.78 a$ & $0.17 a b$ & $0.25 a b$ & $0.11 c$ \\
\hline & $15-20$ & 1.01 & 1.06 & 0.28 & 0.69 & 0.10 \\
\hline & $20-30$ & 0.80 & 1.48 & 0.68 & 0.62 & 0.25 \\
\hline
\end{tabular}

PS90 and PS180 = application of 90 and $180 \mathrm{~kg} \mathrm{~N} \mathrm{ha}^{-1}$ as pig slurry, respectively. DL90 and DL180 $=90$ and $180 \mathrm{~kg} \mathrm{~N} \mathrm{ha}^{-1}$ as deep pig litter, respectively. Means with the same letter are not significantly different from each other by the Tukey test at $p<0.05$.

temperate conditions in the United States (Hansen et al., 2004). These authors found that application of solid manure resulted in a higher organic $\mathrm{P}$ concentration in subsurface soil $(45-65 \mathrm{~cm})$, although liquid and solid manure used did not show much difference in the $\mathrm{P}$ forms evaluated by NMR.

Although solid manure (such as poultry litter) has lower movement capacity in the soil profile than chemical fertilizers (Cade-Menun et al., 2015), our results show that the highest accumulation of both organic and inorganic $\mathrm{P}$ in depth was obtained by applying solid-swine manure (DL) (Table 2). This may be explained by the higher $\mathrm{P}$ input using $\mathrm{DL}$, as explained earlier. Previous studies that evaluated the effect of long-term ( $>8$ years) additions of animal manure (dairy, poultry and swine manure) to agricultural fields also show an increase in soil total P from 1.4- to 8-fold as compared with untreated soils (Dou et al., 2009).

Phosphorus accumulation in soil due to frequent use of high manure doses, regardless of the animal origin, increases the contamination risk of water bodies due to $\mathrm{P}$ transfer from the soil to rivers via runoff. This problem is aggravated when soil is managed in no-till system and manures are applied to the soil surface, resulting in high concentrations of orthophosphate at the soil surface, increasing the risk of $\mathrm{P}$ loss and eutrophication (Cade-Menun et al., 2015). These same authors report nutrient stratification (i.e. high nutrient concentrations at the soil surface) similar to our observations. They suggest that methods must be developed to reduce this stratification, such as injecting $\mathrm{P}$ fertilizers into the subsoil under no-tillage; however, caution should be taken to avoid applying excess $P$ when fertilizing with animal manure. The increase of soil $\mathrm{P}$ in depth observed mainly in the treatment with the highest DL dose may indicate that the soil is close to its maximum $\mathrm{P}$ sorption capacity, meaning that there is potential P loss even by leaching. Similarly to our results, in southern Brazil, after 15 years of pig slurry inputs to an Oxisol, Boitt et al. (2018) observed a vertical movement of $\mathrm{P}$ up to $20 \mathrm{~cm}$ depth; however, the authors concluded that the main form of $\mathrm{P}$ loss was via runoff.

The highest proportion of organic $\mathrm{P}$ at surface layers in the control (Table 2), and the lower proportions of organic $\mathrm{P}$ at surface layers from the treatments receiving $P S$ and DL suggests that inorganic $P$ is added to the treated plots, increasing soil inorganic $\mathrm{P}$ and decreasing organic P. Moreover, it suggests that with no $\mathrm{P}$ additions to the control, the soil inorganic $\mathrm{P}$ is removed by plants, causing an apparent increase in the proportion of soil organic P. Similar results were reported after $\mathrm{P}$ fertilization ceased in a 5-year fertilized grassland in Northern Ireland, suggesting that plants absorb the accumulated inorganic $\mathrm{P}$, with no increase in organic $\mathrm{P}$ mineralization or accumulation (CadeMenun et al., 2017).

A previous work conducted in the same experimental area of our study showed that successive application of PS and DL increased labile inorganic P fractions extracted by anion exchange resin, $0.5 \mathrm{~mol} \mathrm{~L}^{-1}$ $\mathrm{NaHCO}_{3}$, and to a lesser extent for those of intermediate binding energy extracted by $0.1 \mathrm{~mol} \mathrm{~L}^{-1} \mathrm{NaOH}$ (Guardini et al., 2012). Moreover, the authors also found an increase in labile (extracted by $0.5 \mathrm{~mol} \mathrm{~L}^{-1} \mathrm{NaHCO}_{3}$ ) and moderately labile (extracted by 0.1 and $0.5 \mathrm{~mol}$ $\mathrm{L}^{-1} \mathrm{NaOH}$ ) organic $\mathrm{P}$ fractions. However, conventional classification of organic $\mathrm{P}$ bioavailability based on chemical solubility is misleading, because plants might obtain P from supposedly 'stable' fractions of the soil organic P pool (Turner et al., 2005). Additionally, the sequential chemical fractionation method does not provide information on the structural composition of soil $\mathrm{P}$ compounds. This information could be obtained by using $\mathrm{P}$ nuclear magnetic resonance spectroscopy $\left({ }^{31} \mathrm{P}-\mathrm{NMR}\right)$, which provides information on chemicallymeaningful compounds of $\mathrm{P}$ present in soil extracts, improving the understanding on the soil $\mathrm{P}$ chemical nature (Turner et al., 2005; McDowell et al., 2008; Abdi et al., 2014; Cade-Menun and Liu, 2014; Liu et al., 2014; Oliveira et al., 2015; Giles et al., 2015; CadeMenun, 2017). 


\section{$P$ compound classes accessed by ${ }^{31} \mathrm{P}-\mathrm{NMR}$}

Extraction with $\mathrm{NaOH}+$ EDTA solution recovered 35 to $48 \%$ of total $\mathrm{P}$ in the $0-2.5 \mathrm{~cm}$ soil layer (Table 3). These results are in agreement with $\mathrm{NaOH}+$ EDTA extraction recovery rates of $<60 \%,<60 \%$ and $<40$ $\%$, respectively, obtained by Giles et al. (2015) in the United States, and Gatiboni et al. (2013) and Oliveira et al. (2015) in highly weathered soils from southern Brazil. The low $\mathrm{P}$ extraction capacity in our study may be due to the high metal concentrations in the soil (Table 3), which were in excess of extractant chelation capacity (Cade-Menun and Preston, 1996). Accordingly, the interpretation of the $\mathrm{P}$ forms analyzed by ${ }^{31} \mathrm{P}-\mathrm{NMR}$ in our study may not represent all the $\mathrm{P}$ contained in the soil. In this sense, Cade-Menun et al. (2010) highlighted that it is essential to convert relative percentages to concentrations for samples with low total $\mathrm{P}$ recoveries during extraction for ${ }^{31} \mathrm{P}-\mathrm{NMR}$.

One of the major challenges for a better understanding of soil $\mathrm{P}$ dynamics is to estimate organic $\mathrm{P}$ content, as no method can determine absolute concentrations of total organic $\mathrm{P}$ in the soil (Turner et al., 2005). The ignition method involves high temperature to destroy organic matter with subsequent calculation of organic $\mathrm{P}$ by the difference in acid extractable phosphate between ignited and non-ignited samples. As can be seen in Figure 2A, the ignition method tends to overestimate organic $\mathrm{P}$ compared to ${ }^{31} \mathrm{P}-\mathrm{NMR}$, especially in highly weathered soils, such as in the present study, due to the increased solubility of inorganic phosphate minerals after ignition at high temperature. Moreover, considering that $\mathrm{P}$ not extracted by $\mathrm{NaOH}-\mathrm{EDTA}$ is mainly inorganic $\mathrm{P}$, as observed by Cade-Menun et al. (2017), all treatments evaluated showed an average overestimation of the total organic $P$ by ignition of 6.6 times compared to the organic $\mathrm{P}$ levels estimated by ${ }^{31} \mathrm{P}-\mathrm{NMR}$.

Soil organic $\mathrm{P}$ was even more overestimated (about 10 times higher) when estimated by sequential chemical fractionation of Hedley et al. (1982) (Figure 2B). This is because organic $P$ is not directly measured by chemical fractionation. In the Hedley fractionation procedure, as well as in other similar methods, organic $\mathrm{P}$ is calculated as the difference between the total $\mathrm{P}$ extracted with alkaline reactants $\left(\mathrm{NaHCO}_{3}\right.$ and $\left.\mathrm{NaOH}\right)$ and the molybdate-reactive $\mathrm{P}$, thus, assuming that this difference is organic P. However, there are several complex inorganic $\mathrm{P}$ compounds in these extracts that may not react with molybdate, such as pyrophosphate, and they will be accounted for as "organic $\mathrm{P}$ " (Turner et al., 2005). On the other hand, underestimation of inorganic $\mathrm{P}$ evaluated by ${ }^{31} \mathrm{P}-\mathrm{NMR}$ compared to the estimates of inorganic $\mathrm{P}$ by the ignition method (Figure 2C) and by sequential chemical fractionation of Hedley (Figure 2D) was much lower than for organic P $(2.2$ times lower on average).

In the control treatment, the proportion of orthophosphate $(77 \%)$ was lower than in the other treatments that received manure $193 \%$ on average Table 3). Additionally, in the control, proportion of pyrophosphate (a complex inorganic $\mathrm{P}$ compound) was about twice as high than in the treatments with manure application (PS90 and 180, and DL90 and 180), and the proportion of organic $\mathrm{P}$ was about 3.0 to 3.7 times higher (Table 3). This demonstrates that the $\mathrm{P}$ applied as PS and DL is accumulated in the soil preferentially as inorganic P. Similar to our observations for the total organic and inorganic $\mathrm{P}$ contents in the soil (Table 2),

Table 3 - Element extraction by $\mathrm{NaOH}+\mathrm{EDTA}$ and $\mathrm{P}$ compound classes analyzed by ${ }^{31} \mathrm{P}-\mathrm{NMR}$ in the $0-2.5 \mathrm{~cm}$ soil layer for the five treatments at the six soil profile layers for pig slurry (PS) or deep pig litter (DL) applied to supply 90 or $180 \mathrm{~kg} \mathrm{ha}^{-1}$ of N.

\begin{tabular}{|c|c|c|c|c|c|}
\hline Parameter & Control & PS 90 & PS 180 & DL 90 & DL 180 \\
\hline $\mathrm{P}$ added $\left(\mathrm{kg} \mathrm{ha}^{-1}\right)$ & 0 & 303 & 606 & 825 & 1650 \\
\hline \multicolumn{6}{|c|}{ Element extracted by $\mathrm{NaOH}+\mathrm{EDTA}$} \\
\hline$P\left(m g k g^{-1}\right)$ & $178 \mathrm{c}$ & $322 \mathrm{c}$ & $491 \mathrm{c}$ & $873 b$ & $1594 \mathrm{a}$ \\
\hline $\mathrm{P}(\%$ of the total $\mathrm{P})$ & 35 & 44 & 40 & 48 & 46 \\
\hline $\mathrm{Ca}\left(\mathrm{mg} \mathrm{kg}^{-1}\right)$ & $60 \mathrm{~b}$ & $67 \mathrm{~b}$ & $59 \mathrm{~b}$ & $122 b$ & $252 a$ \\
\hline $\mathrm{Mg}\left(\mathrm{mg} \mathrm{kg}^{-1}\right)$ & $12 b$ & $12 b$ & $11 \mathrm{~b}$ & $18 a b$ & $23 a$ \\
\hline $\mathrm{Fe}\left(\mathrm{mg} \mathrm{kg}^{-1}\right)$ & 2174 & 3100 & 3682 & 3238 & 2687 \\
\hline $\mathrm{Al}\left(\mathrm{mg} \mathrm{kg}^{-1}\right)$ & $603 b$ & $714 a$ & $724 a$ & $563 b$ & $533 b$ \\
\hline \multicolumn{6}{|c|}{ P forms analyzed by ${ }^{31 P}-N M R(\%)$} \\
\hline Orthophosphate & 77.1 & 92.7 & 93.5 & 92.3 & 93.5 \\
\hline Pyrophosphate & 1.1 & 0.6 & 0.3 & 0.4 & 0.6 \\
\hline Organic $P$ & 21.8 & 6.7 & 6.2 & 7.3 & 5.9 \\
\hline \multicolumn{6}{|c|}{$\mathrm{P}$ compound classes analyzed by ${ }^{31} \mathrm{P}-\mathrm{NMR}$ ( $\mathrm{mg} \mathrm{kg}^{-1}$ ) } \\
\hline Orthophosphate (inorganic) & 137 & 298 & 459 & 806 & 1491 \\
\hline Pyrophosphate (inorganic) & 11 & 10 & 14 & 29 & 53 \\
\hline Organic P & 39 & 22 & 30 & 64 & 94 \\
\hline Organic/inorganic $\mathrm{P}$ ratio & 0.28 & 0.07 & 0.07 & 0.08 & 0.06 \\
\hline
\end{tabular}

PS90 and PS180 = application of 90 and $180 \mathrm{~kg} \mathrm{~N} \mathrm{ha}^{-1}$ as pig slurry, respectively. DL90 and DL180 $=90$ and $180 \mathrm{~kg} \mathrm{~N} \mathrm{ha}^{-1}$ as deep pig litter, respectively. Means with the same letter are not significantly different from each other by the Tukey test at $p<0.05$. 

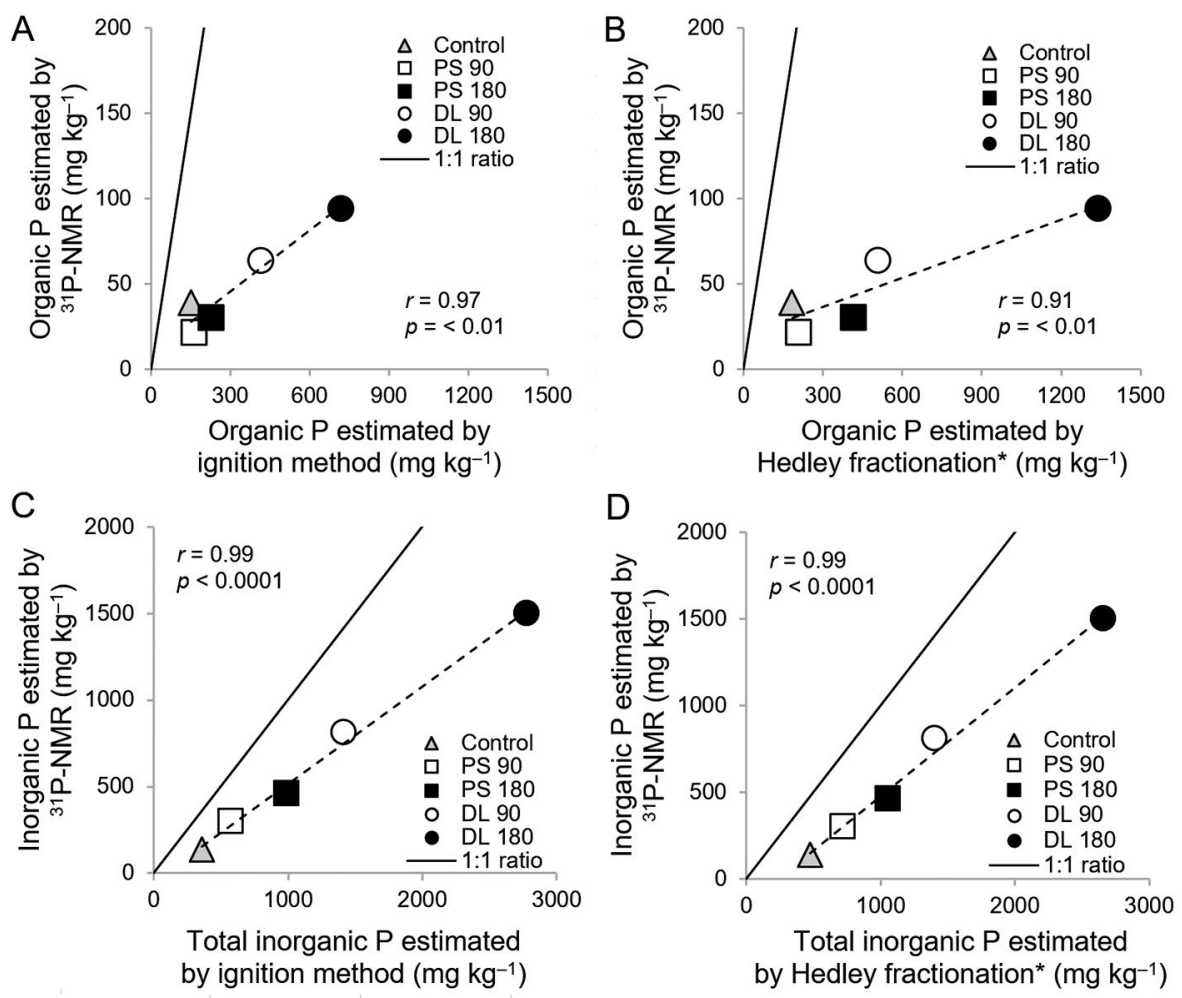

Figure 2 - Comparison between organic ( $A, B$ ) and inorganic (C, D) P content estimated by ${ }^{31}$ P-NMR and the ignition method (A, C) and Hedley sequential chemical fractionation (B, D) at 0-2.5 cm soil layer. *Phosphorus chemical fractionation data obtained from Guardini et al. (2012).

the ${ }^{31}$ P-NMR method (Table 3) also demonstrated that the organic/inorganic-P ratio observed with the addition of both rates of PS and DL was lower than in the control treatment, confirming, therefore, that in soils with no $\mathrm{P}$ addition, crops will absorb inorganic $\mathrm{P}$, increasing the proportion of organic $\mathrm{P}$ in the soil (Cade-Menun et al., 2017).

\section{Conclusions}

The amount of $\mathrm{P}$ applied is one of the main aspects to determine the distribution and accumulation of $\mathrm{P}$ in the soil. The dynamics of $\mathrm{P}$ accumulation in the soil is also controlled by the way swine manure that is applied, as only the DL application increased organic $\mathrm{P}$ in the soil, mainly at the highest dose and in the uppermost soil layers. Applying high manure doses to these soils under no-till management to meet crop $\mathrm{N}$ demand significantly increased $\mathrm{P}$ accumulation at soil surface, especially with DL application. However, this increases the risk of contamination of water bodies due to $\mathrm{P}$ transfer from the soil to the rivers via runoff. The ignition method overestimates organic P compared to P-NMR, possibly due to the increased solubility of inorganic phosphate minerals after ignition at high temperature. The highest proportion of organic $\mathrm{P}$ estimated by both ignition and P-NMR methods, in the surface layers in the control, and the lower proportions of organic $\mathrm{P}$ in the surface layers from the treatments receiving PS and $\mathrm{DL}$ suggests that inorganic $\mathrm{P}$ is added to the treated plots, increasing inorganic $\mathrm{P}$ and decreasing organic $\mathrm{P}$ proportion. Moreover, with no $\mathrm{P}$ additions to the control, the inorganic soil $\mathrm{P}$ is removed by plants, causing an apparent increase in the proportion of organic $\mathrm{P}$.

\section{Authors' Contributions}

Conceptualization: Comin, J.J. Data acquisition: Tiecher, T.; Comin, J.J.; Schmitt, D.E.; Ambrosini, V.G. Data analysis: Tiecher, T. Writing and editing: Tiecher, T.; Brunetto, G.; Rheinheimer, D.; Gatiboni, L.C.; Schmitt, D.E.; Ambrosini, V.G.; Tiecher, T.L.

\section{References}

Abdala, D.B.; Silva, I.R.; Vergütz, L.; Sparks, D.L. 2015. Longterm manure application effects on phosphorus speciation, kinetics and distribution in highly weathered agricultural soils. Chemosphere 119: 504-514. https://doi.org/10.1016/j. chemosphere.2014.07.029

Abdi, D.; Cade-Menun, B.J.; Ziadi, N.; Parent, L-É. 2014. Longterm impact of tillage practices and phosphorus fertilization on soil phosphorus forms as determined by $\mathrm{p}$ nuclear magnetic resonance spectroscopy. Journal of Environment Quality 43: 1431-1441. https://doi.org/10.2134/jeq2013.10.0424 
Agblevor, F.A.; Beis, S.; Kim, S.S.; Tarrant, R.; Mante, N.O. 2010. Biocrude oils from the fast pyrolysis of poultry litter and hardwood. Waste Management 30: 298-307. https://doi. org/10.1016/j.wasman.2009.09.042

Associação Brasileira de Proteína Animal [ABPA]. 2018. Annual Report 2018 = Relatório Anual 2018. ABPA, São Paulo, SP, Brazil. Available at: http://abpa-br.com.br/storage/ files/relatorio-anual-2018.pdf [Accessed July 18, 2019] (in Portuguese).

Cade-Menun, B.; He, Z.; Zhang, H.; Endale, D.M.; Schomberg, H.H.; Liu, C.W. 2015. Stratifcation of phosphorus forms from long-term conservation tillage and poultry litter application. Soil Science Society of America Journal 79: 504-516. https:// doi.org/10.2136/sssaj2014.08.0310

Cade-Menun, B.; Liu, C.W. 2014. Solution phosphorus-31 nuclear magnetic resonance spectroscopy of soils from 2005 to 2013: a review of sample preparation and experimental parameters. Soil Science Society of America Journal 78: 19-37. https://doi. org/10.2136/sssaj2013.05.0187dgs

Cade-Menun, B.J. 2017. Characterizing phosphorus forms in cropland soils with solution ${ }^{31} \mathrm{P}-\mathrm{NMR}$ : past studies and future research needs. Chemical and Biological Technologies in Agriculture 4: 1-12. https://doi.org/10.1186/s40538-017-0098-4

Cade-Menun, B.J.; Preston, C.M. 1996. A comparison of soil extraction procedures for ${ }^{31} \mathrm{P}$ NMR spectroscopy. Soil Science 161: 770-785. https://doi.org/10.1097/00010694-19961100000006

Cade-Menun, B.J.; Carter, M.R.; James, D.C.; Liu, C.W. 2010. Phosphorus forms and chemistry in the soil profile under longterm conservation tillage: a phosphorus-31 nuclear magnetic resonance study. Journal of Environment Quality 39: 16471656. https://doi.org/10.2134/jeq2009.0491

Cade-Menun, B.J.; Doody, D.G.; Liu, C.W.; Watson, C.J. 2017. Long-term changes in grassland soil phosphorus with fertilizer application and withdrawal. Journal of Environmental Quality 46: 537-545. https://doi.org/10.2134/jeq2016.09.0373

Chen, C.R.; Condron, L.M.; Turner, B.L.; Mahieu, N.; Davis, M.R.; Xu, Z.H.; Sherlock, R.R. 2004. Mineralisation of soil orthophosphate monoesters under pine seedlings and ryegrass. Australian Journal of Soil Research 42: 189-196. https://doi. org/10.1071/SR03018

Comissão de Química e Fertilidade do Solo do Rio Grande do Sul e de Santa Catarina [CQFS-RS/SC]. 2016. Liming and Fertilizing Manual for Rio Grande do Sul and Santa Catarina States = Manual de Adubação e de Calagem para os Estados do Rio Grande do Sul e de Santa Catarina. CQFS-RS/SC, Frederico Westphalen, RS, Brazil (in Portuguese).

Empresa Brasileira de Pesquisa Agropecuária [EMBRAPA]. 1997. Manual of Soil Analysis Methods = Manual de Métodos de Análise de Solos. Embrapa Solos, Rio de Janeiro, RJ, Brazil (in Portuguese).

Gatiboni, L.C.; Brunetto, G.; Rheinheimer, D.; Kaminski, J.; Pandolfo, C.M.; Veiga, M.; Flores, A.F.C.; Lima, M.A.S.; Girotto, E.; Copetti, A.C.C. 2013. Spectroscopic quantification of soil phosphorus forms by ${ }^{31} \mathrm{P}-\mathrm{NMR}$ after nine years of organic or mineral fertilization. Revista Brasileira de Ciência do Solo 37: 640-648. http://dx.doi.org/10.1590/S010006832013000300010
Gatiboni, L.C.; Kaminski, J.; Rheinheimer, D.; Flores, J.P.C. 2007. Bioavailability of soil phosphorus forms in no-tillage system. Revista Brasileira de Ciência do Solo 31: 691-699 (in Portuguese, with abstract in English). http://dx.doi.org/10.1590/ S0100-06832007000400010

Gatiboni, L.C.; Smyth, T.J.; Schmitt, D.E.; Cassol, P.C.; Oliveira, C.M.B. 2015. Soil phosphorus thresholds in evaluating risk of environmental transfer to surface waters in Santa Catarina, Brazil. Revista Brasileira de Ciência do Solo 39: 1225-1234. http://dx.doi.org/10.1590/01000683rb cs20140461

Giles, C.D.; Cade-Menun, B.J.; Liu, C.W.; Hill, J.E. 2015. The short-term transport and transformation of phosphorus species in a saturated soil following poultry manure amendment and leaching. Geoderma 257-258: 134-141. https://doi.org/10.1016/j. geoderma.2014.08.007

Guardini, R.; Comin, J.J.; Schmitt, D.E.; Tiecher, T.; Bender, M.A.; Rheinheimer, D.; Mezzari, C.P.; Oliveira, B.S.; Gatiboni, L.C.; Brunetto, G. 2012. Accumulation of phosphorus fractions in typic Hapludalf soil after long-term application of pig slurry and deep pig litter in a no-tillage system. Nutrient Cycling in Agroecosystems 93: 215-225. https://doi.org/10.1007/s10705012-9511-3

He, Z.; Honeycutt, C.W.; Cade-Menun, B.J.; Senwo, Z.N.; Tazisong, I.A. 2008. Phosphorus in poultry litter and soil: enzymatic and nuclear magnetic resonance characterization. Soil Science Society of America Journal 72: 1425-1433.

International Fertilizer Industry Association [IFA]. 2013. Ifadata. Available at: ifadata.fertilizer.org/ucSearch.aspx [Accessed Aug 20, 2019]

Liu, J.; Hu, Y.; Yang, J.; Abdi, D.; Cade-Menun, B.J. 2014. Investigation of soil legacy phosphorus transformation in longterm agricultural fields using sequential fractionation, P K-edge XANES and solution P NMR spectroscopy. Environmental Science and Technology 49: 168-176. https://doi.org/10.1021/ es504420n

Mante, O.D.; Agblevor, F.A. 2010. Influence of pine wood shavings on the pyrolysis of poultry litter. Waste Management 30: 2537-2547. https://doi.org/10.1016/j.wasman.2010.07.007

McDowell, R.W.; Dou, Z.; Toth, J.D.; Cade-Menun, B.J.; Kleinman, P.J.; Soder, K.; Saporito, L. 2008. A comparison of phosphorus speciation and potential bioavailability in feed and feces of different dairy herds using ${ }^{31} \mathrm{P}$ nuclear magnetic resonance spectroscopy. Journal of Environmental Quality 37: 741-752.

Murphy, J.; Riley, J.P. 1962. A modified single solution method for the determination of phosphate in natural waters. Analytica Chimica Acta 27: 31-36. https://doi.org/10.1016/S00032670(00) 88444-5

Oliveira, C.M.B.; Erich, M.S.; Gatiboni, L.C.; Ohno, T. 2015. Phosphorus fractions and organic matter chemistry under different land use on Humic Cambisols in southern Brazil. Geoderma Regional 5: 140-149. https://doi.org/10.1016/j. geodrs.2015.06.001

Olsen, S.R.; Sommers, L.E. 1982. Determination of available phosphorus. p. 403-430. In: Page, A.L.; Miller, R.H.; Keeney, Q.R., eds. Methods of soil analysis. American Society of Agronomy, Madison, WI, USA. 
Soil Survey Staff. 2014. Keys to Soil Taxonomy. USDA-Natural Resources Conservation Service, Washington, DC, USA.

Steffens, D.; Leppin, T.; Luschin-Ebengreuth, N.; Min Yang, Z.; Schubert, S. 2010. Organic soil phosphorus considerably contributes to plant nutrition but is neglected by routine soiltesting methods. Journal of Plant Nutrition and Soil Science 173: 765-771. https://doi.org/10.1002/jpln.201000079

Tiecher, T.; Zafar, M.; Mallmann, F.J.K.; Bortoluzzi, E.C.; Bender, M.A.; Ciotti, L.H.; Rheinheimer, D. 2014. Animal manure phosphorus characterization by sequential chemical fractionation, release kinetics and ${ }^{31} \mathrm{P}-\mathrm{NMR}$ analysis. Revista Brasileira de Ciência do Solo 38: 1506-1514. http://dx.doi. org/10.1590/S0100-06832014000500016

Turner, B.L.; Leytem, A.B. 2004. Phosphorus compounds in sequential extracts of animal manures: chemical speciation and a novel fractionation procedure. Environmental Science \& Technology 38: 6101-6108. https://doi.org/10.1021/es0493042
Turner, B.L.; Cade-Menun, B.J.; Condron, L.M.; Newman, S. 2005. Extraction of soil organic phosphorus. Talanta 66: 294306. https://doi.org/10.1016/j.talanta.2004.11.012

Withers, P.J.A.; Rodrigues, M.; Soltangheisi, A.; Carvalho, T.S.; Guilherme, L.R.G.; Benites, V.D.M.; Gatiboni, L.C.; Sousa, D.M.G.; Nunes, R.D.S.; Rosolem, C.A.; Andreote, F.D.; Oliveira Jr., A.; Coutinho, E.L.M.; Pavinato, P.S. 2018. Transitions to sustainable management of phosphorus in Brazilian agriculture. Scientific Reports 8: 1-13. https://doi. org/10.1038/s41598-018-20887-z

Young, E.O.; Ross, D.S.; Cade-Menun, B.J.; Liu, C.W. 2013. Phosphorus speciation in riparian soils: a phosphorus-31 nuclear magnetic resonance spectroscopy and enzyme hydrolysis study. Soil Science Society of America Journal 77: 1636-1647. https://doi.org/10.2136/sssaj2012.0313 